21 The Displaying of an Horrible Secte of Grosse and Wicked Heretiques, naming themselves the Familie of Love, with the lives of their Authours, and what doctrine they teach in corners (London, 1578), J5r.

22 Benjamin Kaplan, 'Fictions of Privacy: House Chapels and the Spatial Accommodation of Religious Dissent', American Historical Review (2002), 1036.

23 Ibid, 1036.

24 Margaret Aston, 'Segregation in Church', Studies in Church History 27 (1990).

25 Daphne Spain, Gendered Spaces (Chapel Hill NC, 1992), 19.

26 Henry Smith, A Preparative to Marriage (London, 1591), EEBO, 43.

27 Amanda Flather, Gender and Space in Early Modern England (London, 2007), 91-2.

28 On the body and sacred space, see Mary Douglas, Purity and Danger: An Analysis of Conceptions of Pollution and Taboo (London, 1966); Sarah Coakley (ed.), Religion and the Body, (Cambridge, 1997); Rudolf Bell, Holy Anorexia (Chicago IL, 1985); Caroline Walker Bynum, Holy Feast and Holy Fast: The Religious Significance of Food to Medieval Women (Berkeley CA, 1987).

29 Miri Rubin, Mother of God: A History of the Virgin Mary (New Haven CT, 2008).

30 'The Image of Both Churches', in Select Works of Bishop Bale (Cambridge, 1849), 633-4.

31 Mircea Eliade, The Sacred and the Profane: The Nature of Religion, trans. Willard Trask (New York, 1959).

32 Stephen DeStaebler, 'Reflections on Art and the Spirit: A Conversation', in Stephen DeStaebler and Diane Apostolos-Cappadona (eds), Art, Creativity, and the Sacred, (New York, 1984).

33 On space and the doctrine of the Incarnation, see Philip Sheldrake, Spaces for the Sacred: Place, Memory, and Identity (Baltimore MD, 2000).

34 Radical Religion, 101.

35 'Pregnant Puns', 54.

\title{
Performance, Print, and the Senses: Aretino and the Spaces of the City
}

To say that Pietro Aretino (1492-1556) was a man in touch with his senses would be a significant understatement. Aretino frequently evokes what we could describe as different sensory registers in his works. In the process, he opens the door for us into the debates and concerns surrounding the senses in the mid-sixteenth century and creates himself as a character who revels in, or who is assaulted by, the varieties of sensory experience. ${ }^{1}$ Sometimes he 
chooses the descriptive language of art to critique the semblance of something or extol its sublime qualities (from the paintings of Titian to the gift of wine or fruit basket that someone sent him). At other times, he satirizes contemporary Neoplatonic or Aristotelian theories on perception and knowledge, turning them inside-out with wit and derision. And then there are the practices of lived space of which Aretino was an expert observer, not least where they could serve his pen. In what follows, I would like to consider the performance of the sensuous in a few of Aretino's comedies - La Cortegiana (1525, Rome), Il Marescalco (1533, Venice), and La Talanta (1542, Venice) with particular interest in the confluence of these registers of sensory practice as they relate to urban space. The sensorial concerns of the street - selfpresentation, the performance of gender, who sees, hears, touches, or smells whom, who has access to urban and domestic spaces - all of these find a place in Aretino. ${ }^{2}$

Aretino's comedies, modelled on contemporaneous developments in erudite comedy as well as on popular farce traditions, ${ }^{3}$ participate in a redefinition of theatrical space as one that reflects the activity of daily urban life, particularly in the appeal to the collective experience of his audience. Aretino exaggerates this experience, treating the viewer (or reader) to a maelstrom of action, with figures seeming to rush to and fro, leaping on and off the page with frenetic energy. The hubbub of Roman street spaces in La Cortegiana and the constant flow between court space and town space in the streets of Mantua in Il Marescalco are remarkable for their staging of city spaces and movement. The plays are as much about Rome, Mantua, and Venice and the true-to-life movement through these locales as they are about power, persuasion, coercion, and corruption; they demonstrate richly Aretino's powers of observation of the urban world. In La Cortegiana, Histrions I and II describe the cityscape of Rome, taking the audience not only to St Peter's and the Castel San Angelo, but also to The Hare and The Luna, two well-known taverns. The play reminds us throughout of spaces of privilege as well as of the sleazy locales of lowlife, crime, and its punishment. In attending to the action of Il Marescalco, as Leonard Sbrocchi and J. Douglas Campbell have observed in their introduction to the play, 'the audience is made to feel that the space the characters live in extends beyond the boundaries of the stage', with the characters representing those typical of court and town life. ${ }^{4}$ La Talanta also recalls social types and its first performance featured what Peter Brand describes as 'an elaborate perspective set by Giorgio Vasari featuring some of the famous monuments of Rome.' 5 Aretino, by this time 
well established in Venice, seizes the opportunity for frequent comparison between the customs and the geographies of the two cities, not least when he pens a memorable scene with one of Venice's nobles taking in the sights while mounted on a mule.

Through this appeal to daily life, Aretino elaborates several important dimensions of sense experience. One is the formation of knowledge and self-knowledge, which La Cortegiana satirizes and spatializes. For the Renaissance person, the construction of the world and the self is accomplished through sensory experience - it is empirical, relying on the accumulation of exemplary instances to create a relationship between one's self and the social and built milieux. Of particular importance is the way experiences like proprioception - a sense of one's corporeal being in space — are integrated in the way that perception was understood to function. This sensing occurred through what Aristotelian theories called the common sense, an area thought to be in the front of the brain that functioned like a translator of experiential data from the particular sense organs as well as from what Aristotle had called the common sensibles - those actions that any or a combination of specific sense organs could take up. ${ }^{6}$ Understanding arrives through sensation and, without a functioning common sense, one cannot construct the world in an intelligible form. As we shall see, while Aretino does not elaborate the theory, his character, Maco, appears to be handicapped by a lack of common sense. A second area of interest for Aretino is the space of the threshold. Sensory knowledge of the world and of others passes across threshold spaces, into interiors, or out into streets, taking us into an examination of gender and spatiality in La Cortegiana, Il Marescalco, and La Talanta. Critics who work on space theory sometimes read the performative spaces of city life, windows, doorways, and balconies as spaces of male control or female restriction. But in each play, these spaces also represent feminine power as well as the intersection of the sexes, of sounds, sights, and scents. And finally we can observe the confusion, or perhaps rather collaboration, of performance and print as spaces of authorial voice. Aretino claims authority over the urban spaces he knows well through his pen's descriptive power. Writing is a multisensory act in itself. He uses his voice to 'own' the cities in which he sets his plays. These comedies were originally conceived for a particular performance for an elite audience but Aretino clearly appreciated the potential of printed texts to reach a wider audience. He inscribes his particular knowledge in texts that retain a highly oral/aural character; it suffices that they will circulate and 
their readers will see in his imitation a lively space in which they can imagine their own participation and their own superior knowledge.

As Aretino shows, perceptual knowledge is seldom perfect. In La Cortegiana, he specifically critiques Baldassare Castiglione's discussion of the formation of knowledge, both cognitive and practical, as attained through one's vision and hearing, the senses defined by Plato and Aristotle as the true means to rational knowledge. ${ }^{7}$ Appropriate to his wit, and to a play performed at the end of the Carnival season, Aretino inverts them: sight and hearing only lead to sensory confusion and trouble for two would-be courtiers - the Sienese Maco and the Roman Parabolano. Furthermore, much of the direct sensory commentary and situations revolve around bodily appetites - sex and hunger. ${ }^{8}$ Both men of the privileged classes, Maco and Parabolano should, in the gender and class construction of the sensory hierarchy, be governed by their reason; they are, however, blinded by their ambitions and it is instead the servants and the street folk who see things clearly and control the actions of their 'betters'?

Messer Maco, the son of a lesser Sienese noble household, has come to Rome to find his fortune and gain an appointment as a Cardinal. Early in act 1 (scene 2) he meets Master Andrea who tells him that in order to succeed in his designs he must first learn to be the perfect courtier. His sense of sight immediately leads him into a state of befuddlement and the loss of his manservant. Looking up at a window, he spies 'a lady ... dressed in silk and leaning on the windowsill', who inspires immediate love-lust and transforms the dirty jostling street into a site of the 'beautiful' (1.6). ${ }^{10}$ Maco then wanders aimlessly, overcome by his vision, and is confronted by a confusion of doors since he has failed to make note of any landmarks and must rely on others to find him (1.8). This leaves him at the mercy (or merciless ministerings) of a whole host of characters in his quest to be re-formed as a courtier, a cardinal, and a lover. Such is our introduction to this foreigner who thought he was descending on Rome only to have Rome descend upon him.

Theatre historians often describe Maco as stupid beyond belief. ${ }^{11}$ Indeed, he seems to be arrested at the cognitive level of a three-year-old. He believes whatever he is told and only makes half assertions of his own will; he mistakes his words, misspeaking what he has heard ('music' for 'mosaic', for example, as in 2.7 or 'olà' for 'oida' as in 2.20), ${ }^{12}$ and he goes along with clothing changes just as a child would when playing pretend. But he is an adult and his character is comically, and tragically, at a loss when confronted 
with the worldly, fiercely individualistic, and constantly moving Rome that Aretino has created.

But Messer Maco is handicapped by a stupidity more profound than just ignorance. He is a character incapable of learning from or understanding what his senses register. He is a person bereft of common sense. As a man, Maco should be able to take into account what his sight and hearing convey about the world and to act rationally based on that information. But this world is turned upside down and the usual sense-based knowledge does not obtain. Maco instead embodies Aretino's mocking critique of Castiglione's idea of the formation of the individual. Poor Maco, following his eyes and ears, is subjected to physical moulding by hot steam, handed a concave mirror that makes him believe he has been crazily deformed (he has a lack of proprioceptive awareness of his own body and bodily space), and he undergoes a series of costuming changes that re-identify him as someone else while his own garb has been assumed by one of his handlers. If that weren't enough, he has no sense of direction in moral or physical space. The situation is comic since it mocks theories of perception in general, but it also conveys a real concern of early modern life that there is a certain order that should be respected, that accurate empirical understanding of the world should be possible, and that people are supposed to be identifiable by their attire, speech, or look by something that would also normally indicate religion, profession, or civic identity. For example, one of the frequent practical jokes within the play is the cross-dressing of characters against social status or type. The unsuspecting victim then ends up being beaten or arrested for attempting to disguise his true identity. We might not think of this as such a serious matter but, as Bronwen Wilson has shown, there was a substantial concern in the period about maintaining a 'legible system of visual classification' to protect legitimate social order. ${ }^{13}$ Sensorial confusion within the theatrical space may be tolerated and made the subject of laughter (gender cross-dressing also is a favorite device) but a similar confusion outside the playing space presented a potential danger to social stability.

The Roman gentleman Parabolano claims Rome as his natural environment and he is certainly aware of its layers of deception since he has himself sought notice as a courtier. But he too is overcome and undermined by his senses. Like Maco, desire for a woman, 'Laura', makes it impossible for him to register what he really sees and hears. He too is duped because he is deceived by lust, leading him to ignore a worthy servant and fall under the sway of one who is a self-serving, manipulative, and cunning rogue. This is 
the second plot interwoven with the history of Maco. The fact that Parabolano is a gentleman whom Maco was supposed to meet in order to find his way in Rome is just as comic: a case of the blind failing to lead the blind.

Of course, muddled perception is just what Aretino is getting at in his critique of the Roman court - what you see isn't what you get. Words are meaningless without real action and they often represent the opposite of what in fact is going on. Aretino places the audience in the position of having superior moral judgment but he uses Maco's and Parabolano's inability to exercise their own faculties correctly in order to criticize blind ambition and its resulting follies. What the characters need, and their audience requires, is common sense and common experience, which would allow them to decode sensory data effectively so that they would not have to accept situations at first glance (or first hearing).

Figuring among the innovations of sixteenth-century comedic design is the attention to the life of the urban street and its interaction with the domestic interior. As Peter Womack has noted in his work on Serlio, it became increasingly common in the scene design of the period for the stage itself to signify the public street and the off-stage the interiors of private dwellings. ${ }^{14}$ He notes also that one result was that the action frequently took place at threshold spaces, particularly at doorways. ${ }^{15}$ While it doesn't seem that Aretino necessarily intended a Serlio-style perspective stage with a standardized Renaissance city-scape as his background, he certainly organized most of the action by making the street into, to quote sociologist Monica Degen, a site 'of intense sensuous encounter. ${ }^{16}$ In addition to their role in La Cortegiana as a locus of frenetic movement, confusion of identities, and sensorial misapprehension, streets offer place-opportunities for interactions between the urban and the domestic and between public utterance and private confidence. The doorways, windows, and balconies of homes, and the inns, taverns, or barbershops are the loci where people might stretch publicity and privacy in both directions, making the private public but also taking public actions like gossip or the circulation of broadsheets into private or less open spaces. They are also points that intersect at different levels: some are at street level with others slightly or markedly above it, creating different dynamics of looking, hearing, or movement. These two loosely grouped spaces are also frequently stereotyped as gendered, though actual lived practice was usually much more various, as Elizabeth Cohen and others have pointed out. The dramatic action often places women at thresholds, whereas men generally participate in public — inhabiting as their natural element the 
streets, taverns, and barbershops in which they work but also in which the circulation of gossip abounds. This division occurs in Aretino: his women, particularly those of dubious character, be they wife or courtesan, regularly appear at the window or on the balcony. In addition to their notice by the men in the streets, these thresholds serve as points of gossip about women by both sexes. ${ }^{17}$

Balconies and other thresholds figure in the three comedies discussed here. These spaces are inhabited by women engaging in various degrees of display and concealment. We can recall Maco's initial sighting of the courtesan, Camilla, leaning out of her window just after his arrival in Rome (1.6). If the window enables the courtesan's display and the penetration of Maco's gaze from the street below, it can also act as a point of egress, as Maco finds out to his consternation when he is thrown out of that same window onto the street in his nightshirt in act 5 .

Much of Aretino's mention of balconies, windows, or doors occurs in passing in these types of references. In Il Marescalco, however, we also get a sense of women's talk and public concerns about it in the dialogue between Ambrogio and the Marescalco on the punishments of being married (one of which is, evidently, having to listen to women's gossip):

AMBrogio I won't tell you how slanderous they are. They always find something wrong with everyone ... this one doesn't know how to talk, this other one doesn't know how to walk, that one flirts in church, that other one's always on her balcony. In short they criticize one for one thing and another for another - as if they themselves had all the virtues, all the manners, all the charms. $(2.5)^{18}$

This description might be an exaggeration of the accusations some women levelled at others, but it is not a fiction. While he thinks that she may have not much reputation left to lose, La Cortegiana's Ercolano nevertheless harangues his ex-prostitute wife Togna: 'Don't perch up there in the window, showing yourself off like some slut!', to which she retorts: 'The wolves will eat me up' (4.11). ${ }^{19}$

An extended representation of the performative nature of balconies occurs in the Histrion's Prologue to Il Marescalco, in which he impersonates a wife approached at her home by a procuress who spotted her in church. The procuress brings her a letter from an admirer and the rest is played from the balcony:

HISTRION When I'd read the contents I'd make the choice that wise 
women always make. I'd let my lover know from the balcony that I welcomed the message, but not the way the messenger presented it to me. I'd smile like this, bow to him thus, and tilt my head alluringly like this; I'd purse my lips a little like this, then I'd let certain little sighs escape from between them. I'd make such a convincing show of their coming straight from the heart! I'd have such control over my tears and laughters, I'd outdo any strumpet[.] (Prologue) ${ }^{20}$

That more than concerns about vision were involved is implied in this reverie by Blando, in La Talanta:

BLANDO This apartment is very comfortable, and of my liking.

It is true, even so, that the courtesan living nearby prevents my complete satisfaction; because one always sees such scenes as one can observe around similar houses, and one always hears the cries one hears there; it really is too much.

Calling between the street and the window or balcony is presented as a common occurrence in comedy and in life, and not just in attracting the attention of courtesans. Both serenading and vocal insult were frequently described events, as would-be suitors or irate clients might communicate their messages across a threshold that was otherwise closed to them.

These examples lead us to consider the sensory nature of thresholds. As physical spaces, they can be either closed, denying entry, or open, suggesting the possibility of crossing from urban into the domestic environment or vice versa. When we consider them through a perceptual lens, they are actually something in between - not fully permeable and yet rarely opaque: vision can at least partially penetrate windows, balconies, even doorways, and sounds and smells can waft through them. But there is always the possibility of distortion due in part to acoustic properties, currents of air, or other interferences, and in part to distance, which creates the possibility of misinterpretation. The oft-cited virtue of vision and audition were that they were distance senses that didn't require bodily contact with the objects of sensation: as Castiglione rehearses, the 'senses of our body are so deceitful that they often beguile the judgment of our minds as well'. ${ }^{22}$ Equally problematic, however, is the deception that can occur when one lacks direct bodily information to confirm what eyes see and ears hear (or a nose smells, for that matter).

While Aretino does not necessarily make threshold spaces like windows and doors into a point of gossip with the street, he does call to mind the 
surveillance directed toward them from without, observation from within, and their potential as spaces of publicity or as a violation of the domestic sphere. Attention to what one saw or heard seems evident but, depending on the proximity, other sense modalities might come into play, and the accuracy of what one thinks one has observed is always subject to sensory distortion. It is in essence a serious game where reputations are made or lost, where people try to observe without being observed, something that greatly expands the notion of public and private dimensions of the house or of the street. Window or balcony display, therefore, becomes stereotyped, based on real concerns about being able to form clear judgments about who is who based not only on dress, but also on behavioral norms.

Threshold spaces could also be used by women to claim power over their urban-domestic interactions. In La Talanta, for example, the lady-servant Aldella controls access to the house from its thresholds, as well as in the immediate space of the piazza and street outside. At the beginning of the play, Orfinio (one of Talanta's suitors) and his servant Pizio seek admittance to satisfy Orfinio's longing for a view of his lover; Aldella answers from the window:

PIZIO Knock-knock!

ALDELLA Who's there?

ORFINIO It's us.

ALDELLA Letting you in is out of the question; go home, and then you'll know everything.

ORFINIO You're always joking.

ALDELla Don't blame the messenger.

PIZIO Hurry up, open the door!

ALDELLA One who eats from another's table must obey.

ORFInIO Pull the cord, dear lady.

ALDELLA I will leave you to talk.

PIZIO So, the house is closed to us?

ORFINIO It's a pleasantry, just to amuse the lady who wishes to see me in dire straits!

ALDELLA I'm serious, and now I leave you.

Talanta herself periodically appears in the doorway, window, or balcony in lieu of admitting the servant of an admirer, or one of her admirers himself, 
into the house. Admittance is not guaranteed: it is her choice. Speaking from a window might take an otherwise private transaction into urban space, but it preserves the domestic space, even that of a courtesan, as a separate space to which there is no certain entry.

Sensory space in Aretino is not just within the performative aspects of the text or the space of the sala, but in the authorial voice that sounds its control over the spaces represented. This authorial and performative voice is always there. Aretino lays claim to the places he describes and inscribes through the language and action of the street, and derisive, satirical laughter. His characters likewise claim and clamour for agency over the spaces they inhabit, sense, and manipulate. One has the impression, particularly in La Cortegiana and Il Marescalco, that once Aretino starts writing, the words literally tumble out of him, forming a large and lively linguistic and physical gesture that takes on a life of its own. The comedies discussed here are works that are highly self-referential; the deeds and successes of Aretino recalled for his audience include the notorious Pasquinades and the statue of Pasquino in Rome with which they were associated. His own impressive knowledge of things, people, and places is repeatedly demonstrated in bravura catalogues of the names of important dignitaries or artists, or the wares of witchcraft, for example. And he is one of the subjects of gossip exchanged by his characters.

But he also orchestrates gossip and uses it as an organizing force, for example in Il Marescalco. Basing the five-act structure on a practical joke that is the subject of endless rumour and gossip, he produces a work that preserves its oral/aural qualities even when consumed in print (it was, after all, as printed text that Aretino's work reached a wider audience) and that even seems to extol the ability of print to create that 'out loud' quality of riotous dialogue. One character after another presents himself or herself to the Marescalco to offer congratulations and to extol the supposed virtues of the intended bride. The text frequently cues movement through the action described in dialogue ('I see', 'Here comes') because it offers no stage directions, a printing choice common in sixteenth-century beffa and improvised comedy. No one actually sees the bride until the end - she is completely constructed by rumour. In this instance, the focus on experience within the play is completely removed, in contrast to La Cortegiana, and everything is sustained through the gossip mill itself. Aretino appeals to the audience's experience of gossip, its social roles and dangers. Likewise, the physically absent Duke of Mantua is an aural presence who controls the action throughout because of the constant reference to him by other characters. While Aretino creates the duke as the 
master puppeteer running an elaborate joke, Aretino has in fact ceded nothing, controlling the comedy's duke to serve his own ends, whatever they may have been. 24

One of the re-formations of theatrical space in the first half of the sixteenth century in Italy had to do with the re-forming of performative scripts and scenarios into text editions meant for a public of readers rather than watchers. They become part of the overlapping spheres of publics and publicity that were ever more densely woven through the late Renaissance city space. Even so, these are early days for text adaptations, and stage directions are few and far between: as Di Maria reminds us, the reader must imagine the action and sensory events through the semiotic cues in the text — 'here', 'there', 'let's go in the house', 'what's that sound', and so forth. ${ }^{25}$ In this way they are called upon to cross that sensorial threshold and imaginatively participate in the played space re-presented on the page. One thing not left to their imagination is the role that Aretino has created for himself with references to his own alter ego Pasquino, his close friends and associates, and his personal triumphs all there for the reader within the text as the comedies become another element of his public image making. Writing his real self into the space of the comedy adds another layer of the verisimilitude that was created through the inclusion of street scenes, practices, contemporary notables, and important ideas.

These are but a few of the ways that sensory space is re-enacted by Aretino. His comedies lie along a continuum of works that represent evolving spaces of gathering and publicity that are also described in archives, chronicles, and diaries - private homes, taverns and inns, barbershops, streets, pharmacies, squares, the spaces of more formal academies, and spaces dedicated to theatrical performance. In fact, he has to include a certain level of realistic depiction of everyday experience in order to create a need for his own inclusion as an absent (and yet highly present) character in the plays and to generate a knowledge space in which the collective experience of the audience can find resonance. While his immediate intent is to entertain an elite audience who could imagine itself positioned above the characters portrayed, socially and voyeuristically, what he has to offer us is another resource in thinking about the spaces of common knowledge and association in Rome, Mantua, or Venice, and the sensory relations between performance and the everyday, the stage and the street. 


\section{Notes}

I would especially like to thank Paul Yachnin and also my research assistant, Diana Chiriac, who was of considerable help in the early reading and discussion of the plays.

1 Sensory references abound in the comedies under discussion here but Aretino is perhaps at his most fluent in this regard in his letters.

2 Elizabeth Cohen, 'To Pray, To Work, To Hear, To Speak: Women in Roman Streets c. 1600', Journal of Early Modern History 12 (2008), 289-311. I follow Cohen's usage of 'urban' and 'domestic' over the oft-used 'public' and 'private' since they imply, as she has observed, a more nuanced use of these spaces.

3 For placement of Aretino's comedies within sixteenth-century developments and Aretino's use of erudite structures and situations alongside the interest in contemporary life, see Richard Andrews, Scripts and Scenarios: the Performance of Comedy in Renaissance Italy (Cambridge, 1993); Peter Brand, 'Aretino and Later Comic Playwrights', Joseph Farrell and Paolo Puppa (eds), A History of Italian Theatre (Cambridge, 2006), 74-83; and M.T. Herrick, Italian Comedy in the Renaissance (Urbana, 1966).

4 Leonard G. Sbrocchi and J. Douglas Campbell, 'Introduction', in Pietro Aretino, The Marescalco [Il Marescalco], Trans. Leonard G. Sbrocchi and J. Douglas Campbell (Ottawa, 1986), 15. Sbrocchi and Campbell additionally note that it is not only the cast of characters that help create a sense of verisimilitude, but also the numerous references to other town folk that would be part of normal Renaissance town life. By referencing 'the town fool, Ser Paolo, the Nurse's parish priest, and the barber [Aretino] evoke[s] a sense of a living community' and other such mentions help to bear this out (10). Salvatore Di Maria, The Italian Tragedy in the Renaissance: Cultural Realities and Theatrical Innovations (Cranbury, NJ, 2002), has also noted the various semiotic codes used to express the text in order to engage a 'strong sense of spatial proximity between the audience and the stage' (129).

5 Brand, 'Aretino and Later Comic Playwrights', 76.

6 For a recent discussion, see Daniel Heller-Roazen, The Inner Touch: Archaeology of a Sensation (New York, 2007).

7 Baldassare Castiglione, The Book of the Courtier [Il Cortegiano], ed. Daniel Javitch, trans. Charles S. Singleton (New York, 2002). Book 2 contains the relevant debates on the appropriate use of the senses and their capacity to deceive.

8 See John Biow's discussion, In Your Face: Professional Improprieties and the Art of Being Conspicuous in Sixteenth-Century Italy (Stanford, 2010). 
9 Aretino is rehearsing part of the debates on vision, and may be picking up on a thread that appears in Castiglione when messer Federico counsels 'there are many reasons why our eyes are wanting in discernment, it is by ambition that they are especially blurred' (70).

10 Pietro Aretino, The Courtesan [La Cortegiana], in Donald Beecher (ed), Renaissance Comedy: The Italian Masters, vol. 1 (Toronto, 2008), 122.

11 My favourite is Richard Andrews's description of Maco as 'a character so breathtakingly stupid as to enter the realm of pure cardboard fantasy' (Scripts and Scenarios: The Performance of Comedy in Renaissance Italy, Cambridge, 1993, 67).

12 Aretino, The Courtesan, 142 and 150. As Beecher has also discussed in his introduction to the plays in this volume, the mixing up of words and meanings was a useful, and familiar, comic device (3-35). Aretino employs it as well in conversations between the Pedant and Stableboy characters in The Marescalco.

13 See Bronwen Wilson, The World in Venice: Print, the City, \& Early Modern Identity (Toronto, 2005), in particular her discussion 'Costume and the Boundaries of Bodies'. Venice was an extreme case, attempting to legislate every aspect of clothing practice, and they took seriously any breach of law in this regard. While they seemed especially concerned about clearly reflecting one's religious identity (Christian, Jew, Muslim), masquerading as one's social superior could also lead to trouble. And throughout the sixteenth century, sumptuary laws were enacted and revised in Rome and Venice to address this very problem and to distinguish clearly, for example between courtesans and noble ladies. For an intriguing and related discussion of Aretino and clothing, see Susan Gaylard, "Naked Truth": Clothing, Patronage, and Genius in Aretino's Letters', The Italianist 8 (2008), 179-202.

14 Peter Womack, 'The Comical Scene: Perspective and Civility on the Renaissance Stage', Representations 101 (Winter 2008), 43.

15 Ibid.

16 Monica Montserrat Degen, Sensing Cities: Regenerating Public Life in Barcelona and Manchester (London, 2008), 3.

17 For discussion of gossip and the multivalent space of the street in both Rome and Venice, see Elizabeth Cohen, 'To Pray, To Work, To Hear, To Speak'; Alexander Cowan, 'Gossip and Street Culture in Early Modern Venice', Journal of Early Modern History 12 (2008), 313-33; and Elizabeth Horowodich, 'The Gossiping Tongue: Oral Networks, Public Life and Political Culture in Early Modern Venice', Renaissance Studies 19.1 (2005), 22-45.

18 Aretino, 'Prologue', The Marescalco, 61.

19 Aretino, The Courtesan, 173.

20 Aretino, 'Prologue', The Marescalco, 39. 
21 Pietro Aretino, La Talanta, in Giovanna Rabitti, Carmine Boccia, and Enrico Garavelli (eds), Teatro, Vol. 2 (Il Marescalco, Lo Ipocrito, Talanta) (Roma, 2010): 417 (my translation).

22 Castiglione, The Book of the Courtier, 66.

23 Ibid, 369.

24 For an interesting speculation on the action of Marescalco and the carnivalesque aspect of this ducal manipulation, see Deanna Shemek, 'Aretino's Marescalco: Marriage Woes and the Duke of Mantua', Renaissance Studies 16.3 (2002), 366-80.

25 Di Maria, The Italian Tragedy in the Renaissance. Di Maria devotes an interesting and significant discussion to the specific role of sound in the theatre and one work that he examines in detail is Aretino's tragedy, Orazio.

\section{'What makes thou upon a stage?': Child Actors, Royalist Publicity, and the Space of the Nation in the Queen's Men's True Tragedy of Richard the Third}

At the opening of one of their signature histories, The True Tragedy of Richard the Third, the Queen's Men go out of their way to reassure their audience that what follows will not be a pretentious, inscrutable art play. Yes, a shieldbearing ghost has just crossed the stage crying out for revenge in Senecan Latin, ${ }^{1}$ and yes, a pair of precocious boys in allegorical women's clothing now claim our attention. ${ }^{2}$ Children of some elitist chapel, perhaps? Students from some privileged school? These were tropes that were current not only in London, but also in venues along the Queen's Men's provincial touring routes where local nobility patronized choirboys as well as adult companies, and schools taught public speaking through play-making. But the boys who start the show do not expect their audience to treat the symbolic neoclassical gestures of those opening moments with reverence. The first boy greets the second with a helpful 'Truth well met', and the second reciprocates, 'Thankes Poetrie'. Then Truth asks Poetry, in teasing reference to the Latin-speaking ghost, 'what makes thou vpon a stage?' Within six lines of the ghost's entrance, we are assured that we will not be abandoned to the pretentious devices of Poetry, who by her own admission makes only 'shadowes' on that stage. 'Then will I adde bodies to the shadowes', Truth responds, 'Therefore depart and giue Truth leave / To shew her pageant' (9-14). It is 